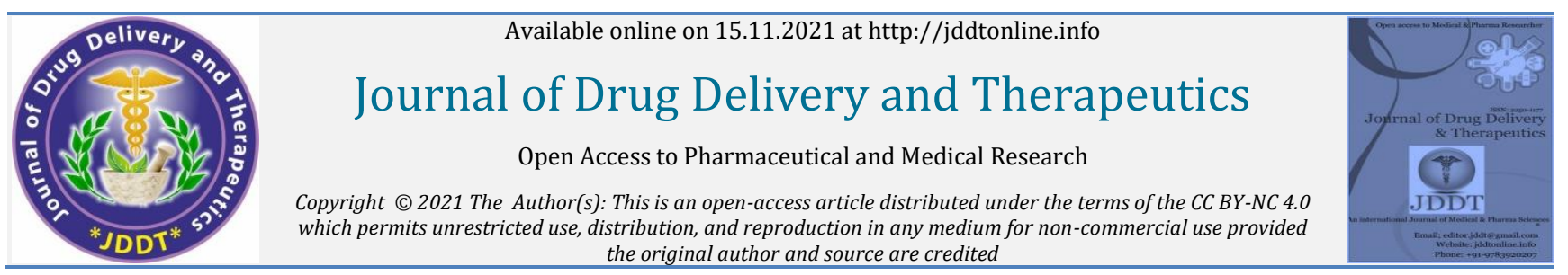

Open Access Full Text Article the original author and source are credited
and

Review Article

\title{
Floating Drug Delivery System an Aid to Enhance Dissolution Profile of Gastric
}

\author{
Yadav Shalini (D*), Yadav Saurav (D), Mishra Amar, Kumar Ashutosh and Kushwaha S. Sandhya \\ Dr. M.C. Saxena College of Pharmacy, IIM Road-Lucknow, Uttar-Pradesh, India
}

Article Info:

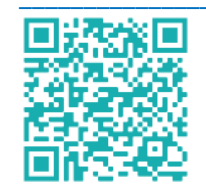

Article History:

Received 21 September 2021 Reviewed 30 October 2021

Accepted 05 November 2021

Published 15 November 2021

\section{Cite this article as:}

Yadav S, Yadav S, Mishra A, Kumar A, Kushwaha SS Floating Drug Delivery System an Aid to Enhance Dissolution Profile of Gastric, Journal of Drug Delivery and Therapeutics. 2021; 11(6):286-296

DOI: http://dx.doi.org/10.22270/jddt.v11i6.5153

*Address for Correspondence:

Yadav Shalini, Dr. M.C. Saxena College of Pharmacy, Lucknow, Uttar-Pradesh, India

ORCID ID: https://orcid.org/0000-0001-6667-3935

\section{Abstract}

With the GRDDS, the dose shape remains controllably in the stomach after oral administration, so that the medication may be continually delivered to its absorption receptors in the intestinal tract. The medicine is delivering in a controlled and extended way. Gastro-retentive dose in the stomach area may last for another few hours and substantially lengthen the gastric residence period of the medicines. While the bulk density in the system for the supply of floating medicines (FDDS) exceeds the gastric fluids, it remains for an extended duration in the stomach without altering the rate of decomposition. The medication distributes gradually as the system floats on the stomach juice. As a consequence, stomach residency takes longer and plasma concentrations are well monitored. The therapy of peptic ulcer illness might be beneficial for local activity in the upper portion of the intestine, i.e., a longer stomach residency. In addition, medicines rapidly absorbed in the GI tract will increase bioavailability through delayed stomach release. The regulated gastric retention of solid dose forms can also be accomplished by the simultaneous administration of pharmacological agents, or by sedimentation, flotation processes, muco-adhesion, expansion, changed shape systems, by delaying the stomach emptying.

Keywords: Gastro-retentive drug delivery system, Floating drug delivery system, Mucoadhesion, Bioavailability.

\section{INTRODUCTION}

Whereas drug delivery has advanced enormously, oral administration has garnered greater emphasis and success, as gastrointestinal physiology allows more dose form versatility than other approaches. The use of gastroretentive systems is the oral technique for prolonged medication release. The goal is to increase the delivery duration of drugs in the gastric region ${ }^{1}$. For medical compounds with poor solubility and weak intestinal resistance, fluid drug delivery systems (FDDS) for the stomach retaining of the drug have been created. The premise for FDDS is to reduce the density of the dose form to have it float on them. FDDS are low-density hydraulically operated systems with adequate boosting to float above the stomach content and remain in the stomach flourishing for a longer amount of time without influencing the gastric vacuum rate. The remaining system is Evacuated with the medication release from the stomach. This leads to increased gastric dwell duration and management of variations in plasma medicinal products. The idea of flourishing preparation provides a simple and practical technique for increasing stomach residence duration for the dose and long-term release of medicines ${ }^{2}$. In order to achieve better therapeutic effectiveness of the medication substance in some conditions, it is desired to extend the stomach retention of an administered system. Medication which are less accessible and destroyed by alkaline $\mathrm{pH}$ exhibit greater absorption in the proximal portion of the gastrointestinal tract have prolonged gastric retention. Moreover, prolonged gastric retention and thus various advantages, including enhanced bioavailability and therapeutic efficiency with decrease of dosage frequency, are offered for the continuous supply of medicines to the belly and proximal small gut in the treatment of some ulcers $^{3}$. Gastro-retentive dosage forms (GRDF) are intended to be retained and released in the gut for an extended duration of time and therefore enable the medication to be continuously and prolongedly input into the upper section of the gastrointestinal tract (GI). In recent decades, this technique has attracted considerable attention because of its potentials to improve oral delivery of several essential medicines, which are likely to substantially increase the oral bioavailability and/or therapeutic result of prolonged retention in the upper GI tract ${ }^{4}$.

Part of the proximal developed by fundus in the stomach. The body is the reservoir for ungroomed materials, and the antrum is the primary location for the mixing of gestures and serves as a stomach emptying pump by action pushing5,6. In both the fasting and fed phases, gastric emptying takes place. In fasting conditions, the inner digestive myoelectric migrating cycle (MMC) is split into four phases and is held in a 2-3-hour period7. 
* Phase I (base phase) with frequent contractions lasting between 40 and 60 minutes.

* Phase II (pre-burst phase) takes 40 to 60 minutes with sporadic activity and contraction potential.

* Phase III (starting phase) takes between 4 and 6 minutes. It contains strong and regular short-term contractions. Because of this wave, all the non-digested material is drawn down into the small Dram from the stomach. The housekeeping wave is also known.

* Phase IV lasts between 0 and 5 minutes, occurs respectively phase III and phase I in two consecutive cycles.

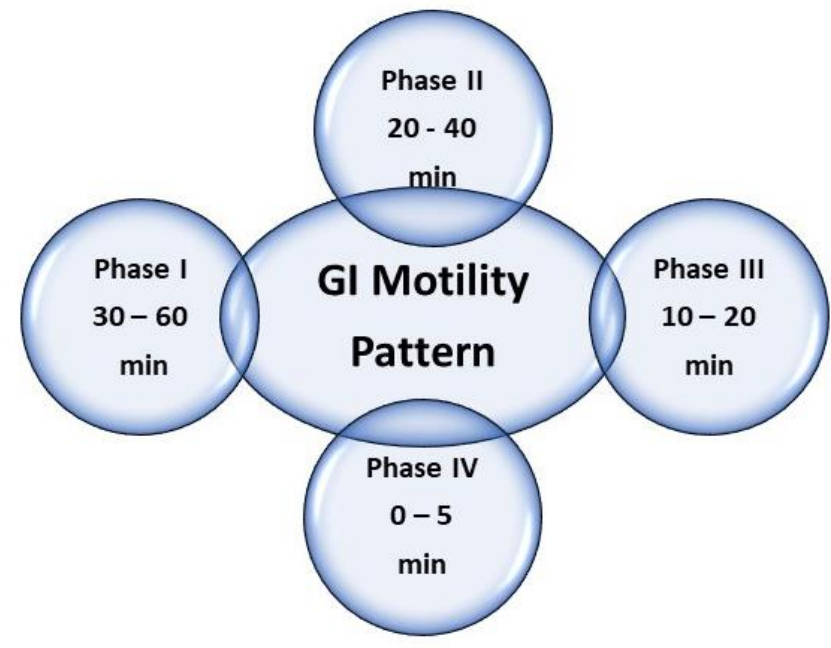

Figure 1: GIT motility model

The rate of contractions differs between fasting and one in the gastric phase when a combination meal is consumed. This is also coined as the regularity of intestinal motility and involves continuous contractions in fasting condition Phase II. These contractions reduce the proportion of the suspended nutrient particles (to below $1 \mathrm{~mm}$ ) to the pylorus. During MMC's feedstock start, the stomach emptying rate is slowed 8,9 .

\section{PRINCIPLE TYPES OF GASTRIC RETENTION SYSTEMS}

The gastro-retention systems are intended for extended time to be kept within the stomach to release the active components of the drugs and allow the medication to enter the upper section of the gastrointestinal tract on a continuous and prolonged basis. Over recent decades, this technique has received huge attention because of its potential to improve the oral administration of several essential medicines, which are able to improve their oral bioavailability and/or therapeutic effect with longer retention in the upper GI tract.

Ideal candidates for the delivery of gastro-retention medicines:

* A drug that acts in the stomach locally.

* Medications that are mostly taken in the stomach.

* Medicines those are not very soluble in alkaline ph.

* Medicines that are quickly absorbed by the GI tract.

* Medications in the intestines that deteriorate.

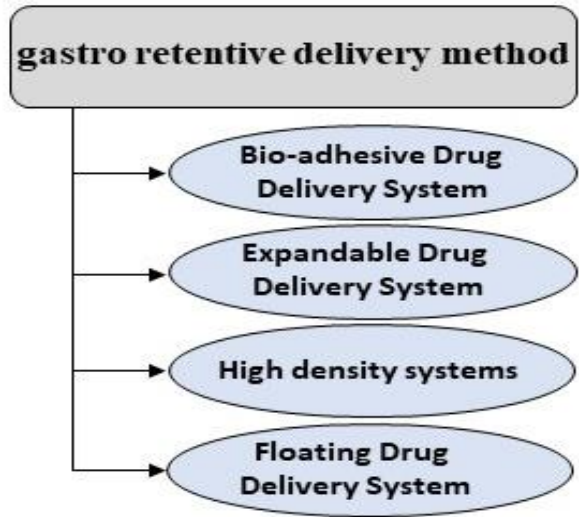

Figure 2: Categorized as following gastro retentive delivery method.

1. Bio-adhesive systems: As a feeding device in the lumen, bio-adhesive devices are utilized to improve pharmaceutical absorption on site. In this technique, we employ bio-adhesive polymers that can fix on the epithelial membrane of the stomach ${ }^{10}$. Bio-adhesive systems attach to gastric or mucous epithelial cells and increase stomach retention by enhancing the closeness and durability of contact between the GRDDS system and biological membrane. Perhaps one among the prosperous except that polycarbophil, Carbopol, lectins, chitosan, gliadin, alginate etc. have been frequently employed in those systems. The capacity to maintain a drug's adherence to the mucous layer offers a longer period of residence at a certain organ location and therefore improves or systemic jolt on the local activity.

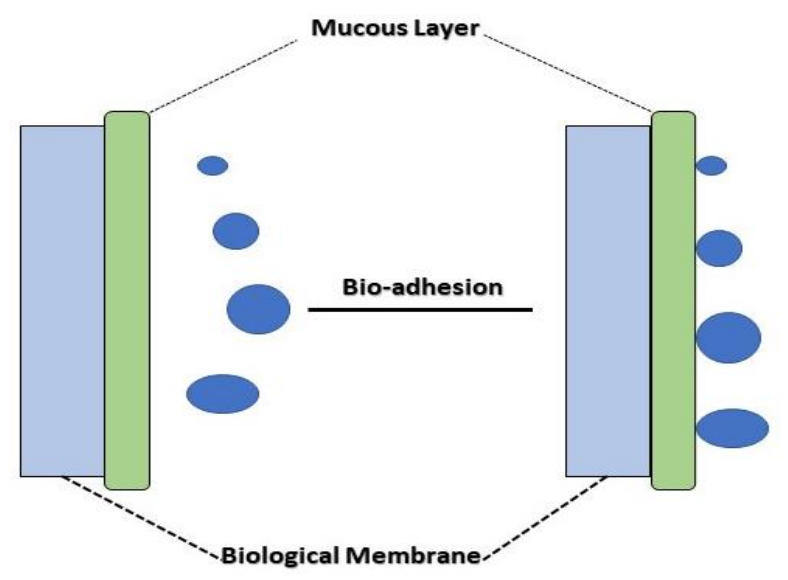

Figure 3: Bio-adhesive mechanism of drug molecule on mucous layer

2. Expandable systems: Extensile gastric retentive systems are readily ingested, and owing to swelling or developing processes, the stomach retention duration is much higher ${ }^{11}$. When the stomach is evacuated after release, its proportions are decreased. A merger of significant dimensions and high dose stiffness increases gastroretentiveness to endure peristalsis and mechanical stomach contractility. The in vivo absorption effects were enhanced by narrow absorption window medicines in these systems. This system's expansion mechanism swells in a way that impedes the pylorus from exiting. The dose form is therefore kept for a long time in the stomach. These can be referred to as "plug-type system" since they tend to remain lodged on the pyloric sphincter when the diameter in their enlarged condition exceeds around $12-18 \mathrm{~mm}$. The recipe is designed to store the medication in a stomach cavity and to regulate it. 
For several hours, even in the fed condition, such polymer matrices persist in the stomach cavity.

3. High density systems: This technique comprises the creation of dose shapes with densities which must exceed the usual stomach content density $(\sim 1,004 \mathrm{gm} / \mathrm{cm})$. This sort of formulations is created by covering the medicine in a hefty core or 3 mixed with inert ingredients. Barium sulphate, iron powder, zinc oxide and titanium oxide etc. are the inert materials. Material density up to $1,5-2,4 \mathrm{gm} / \mathrm{cm}$ rises. For a considerable extension of 3gastric residency period, a density of over $32.5 \mathrm{gm} / \mathrm{cm}$ seems essential ${ }^{12}$.

4. Floating drug delivery system: Floating systems are moderate systems that hover over the intestinal fluid and exist in the stomach for a considerable length of time ${ }^{13}$. The medication is slowly released from the system when the gastric content is released and the rest of the system is removed from the stomach at the correct rate after the drug is administered. As a consequence, stomach retention is improved and the variations in plasma drug concentration are better controlled ${ }^{9}$. The medication is released slowly at the required concentration in the circulation as the system floats in stomach content. The debris from the stomach is therefore cleansed. These findings will result in GRT increase and improved flux management at concentrations of plasma drugs. However, the floating style minimum level (F) requires also that floats on the surface of meals provide a dependable dose form for the stomach content that is minimal to acquire a right to retain the concept of flooding ${ }^{14}$. It is also beneficial for local medicines such as antibiotics for Helicobacter pylori for proximal gastrointestinal (GI) treatments for a peptic ulcer ${ }^{15}$ and for medications difficult to dislocate or not durable in gastrointestinal secretions ${ }^{16}$.

Table 1: Elucidation of merits and the downsides of floating drug delivery system

\begin{tabular}{|c|c|c|}
\hline S.No & Merits & Downsides \\
\hline 1. & $\begin{array}{l}\text { In comparison with non-GRDF CR polymer formulation, } \\
\text { the bio-availability of various medicines (such as } \\
\text { riboflavin and levodopa) CR-GRDF is considerably } \\
\text { improved }^{17} \text {. }\end{array}$ & $\begin{array}{l}\text { The main drawback of a floating system is that gastric } \\
\text { juices have to float without a sink in adequate amounts. The } \\
\text { utilization of bio adhesive polymers that attach readily to } \\
\text { stomach mucosa can, however, circumvent this } \\
\text { restriction }{ }^{21} \text {. }\end{array}$ \\
\hline 2. & Simple and traditional formulation procedure. & Not appropriate for GIT solutions or stability issues ${ }^{22}$. \\
\hline 3. & In the treatment of reflux problems (GERD) [30]. & $\begin{array}{l}\text { The medications that are unsustainable in the acidic gastric } \\
\text { environment are not worthy choice for integration in the } \\
\text { systems }{ }^{22} \text {. }\end{array}$ \\
\hline 4. & $\begin{array}{l}\text { The FDDS is beneficial for medications with stomach } \\
\text { absorption such as antacids and ferrous salts }{ }^{18} \text {. }\end{array}$ & $\begin{array}{l}\text { Up an entire water glass should be offered to the dose form } \\
(200-250 \mathrm{ml})^{23} \text {. }\end{array}$ \\
\hline 5. & $\begin{array}{l}\text { FDDS minimises variation of medication concentration } \\
\text { over a threshold level and promotes pharmacodynamic } \\
\text { and pharmacokinetic benefits }{ }^{19} \text {. }\end{array}$ & $\begin{array}{l}\text { These methods offer no substantial benefits compared to } \\
\text { typical drug-dose forms absorbed via the gastrointestinal } \\
\text { tract }{ }^{23} \text {. }\end{array}$ \\
\hline 6. & $\begin{array}{l}\text { A floating dose form is generally recognised, especially } \\
\text { with medicines that have limited absorption sites in the } \\
\text { upper gut }{ }^{20} \text {. }\end{array}$ & $\begin{array}{l}\text { Two medicines like nifedipine that are well distributed } \\
\text { throughout the GIT and undergo first-pass metabolism may } \\
\text { not be optimal }{ }^{24} \text {. }\end{array}$ \\
\hline 7. & Easier patient compliance administration. & $\begin{array}{l}\text { Medicines that are irritating to stomach mucosa are either } \\
\text { not desirable or are not appropriate. }\end{array}$ \\
\hline
\end{tabular}

Criteria for selecting drug applicants for the system of floating medicines: $25,26,27$

- Medicines with limited window absorption in GIT (e.g. LDOPA, paminobenzoic acid, furosemide, riboflavin).

- Drugs that are effective regionally in the stomach (e.g. misroprostol, antacids).

- Drugs in the intestine or colonic environment that are unstable (e.g. captopril, ranitidine $\mathrm{HCl}$, metronidazole).

- Medicines which trouble typical colonic bacteria (e.g. antibiotics used for the treatment of Helicobacter pylori, such as tetracycline, clarithromycin, amoxicillin).

- Medicines with low high pH dissolution. (e.g. diazepam, chlordiazepoxide, verapamil).

\section{FLOATING SYSTEMS MECHANISM:}

Floating drug delivery devices (FDDS) have a relative density lower than stomach juices and are therefore suspended in the digestive system for longer periods of time without impacting the the pace of digestion. During floating on the stomach contents, the medication is freed at the recommended intervals from the system. The residual system is emptied of the stomach once the medication is released. The GRT is improved and variations in plasma medication concentrations are better controlled. However, a minimum amount of floating force $(F)$ is necessary in inclusion to the minimal gastric content needed to assure that the floating force is properly maintained in the dose forms on the meal's surface. A new apparatus for determining the resulting weight was published in the literature for the appraisal of floating force kinetics. So to retain the submerged item, the device continually measures the force corresponding to $\mathrm{F}$ (depending on time). If $\mathrm{F}$ is on the upper positive side, the item floats better. This device serves to optimise the stability and endurance of the floating forces produced by FDDS, to avoid unpredictable fluctuations in intra-gastric buoyancy 35 .

$\mathrm{F}=\mathrm{F}$ buoyancy $-\mathrm{F}$ gravity $=(\mathrm{Df}-\mathrm{Ds}) \mathrm{gV}$

Where, $\mathrm{F}=$ total vertical force,

$\mathrm{Df}=$ fluid density,

Ds = object density,

$\mathrm{V}=$ volume and

$\mathrm{g}=$ acceleration due to gravity. 

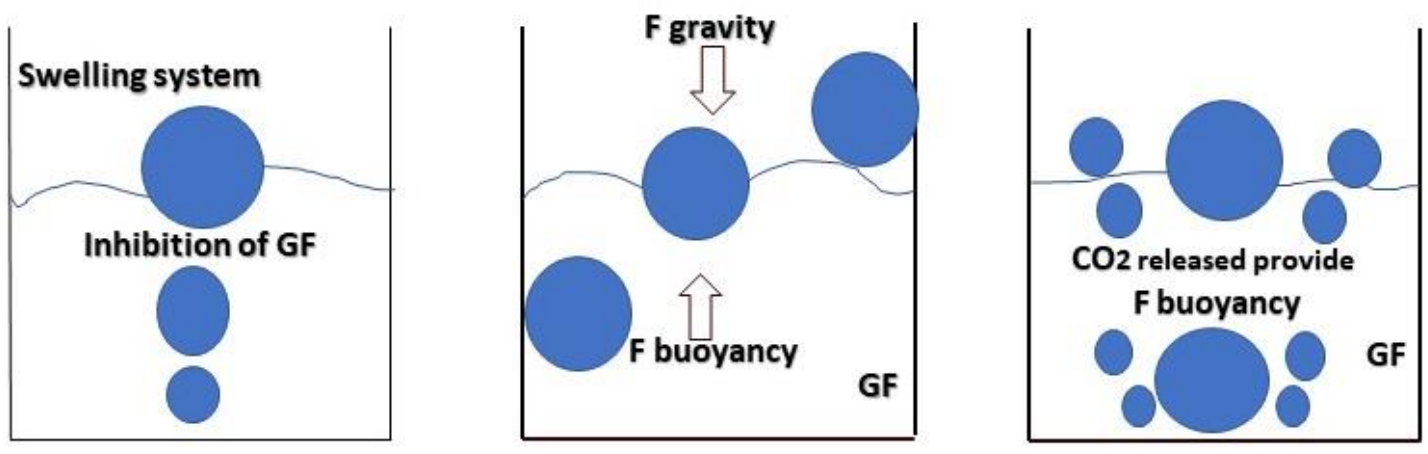

Figure 4: Mechanism of floating drug delivery system

Table 2: Relative comparison between conventional and gastro-retentive drug delivery system

\begin{tabular}{|c|l|l|l|l|}
\hline S.No & Relative Parameters & $\begin{array}{l}\text { Conventional Drug Delivery } \\
\text { System }\end{array}$ & Gastro Retentive Drug Delivery System & Ref. \\
\hline 1. & Toxicity & High toxicity concern. & Very little toxicity concern. & 28 \\
\hline 2. & $\begin{array}{l}\text { Low solubility and high pH } \\
\text { drugs }\end{array}$ & $\begin{array}{l}\text { Not suited for supply in the } \\
\text { small intestine area with } \\
\text { narrow absorption windows. }\end{array}$ & $\begin{array}{l}\text { Sutiable for supply in the small intestine area } \\
\text { with narrow absorption windows. }\end{array}$ & 29 \\
\hline 3. & Compliance with the patient & Low & Enhanced & 28 \\
\hline 4. & $\begin{array}{l}\text { Drugs that operate in the } \\
\text { belly regionally }\end{array}$ & $\begin{array}{l}\text { Not very beneficial for GIT- } \\
\text { fast-absorbing medicines. }\end{array}$ & $\begin{array}{l}\text { Very beneficial to medicines in the stomach } \\
\text { locally. }\end{array}$ & 29 \\
\hline 5. & Dose dumping & No dosage risk dumping. & Chance to dump. & 28 \\
\hline
\end{tabular}

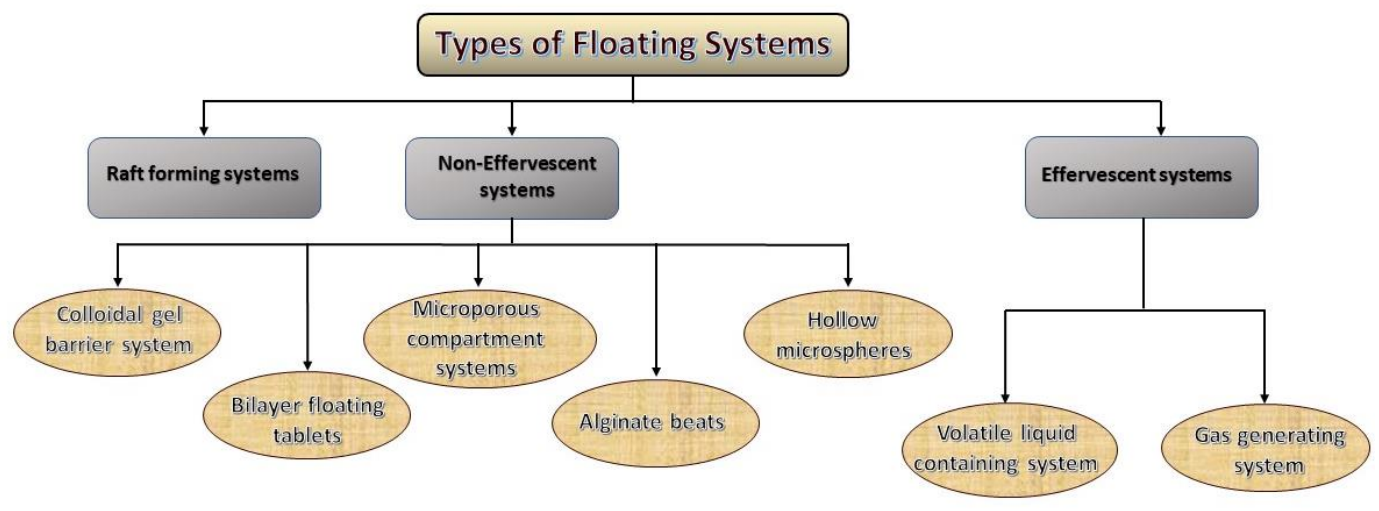

Figure 5: Floating system classification ${ }^{31}$

A. Non-Effervescent Systems: These are single-unit forms of hydrophilic polymers, with more than one gelforming aspects. Although the most frequent kind is hydroxypropyl-methylcellulose, sodium carboxymethyl-agar, carrageen and alginic acid are also employed. Alternatively, hydroxypropyl-methylcelluloses (HPMC) are most prevalent in usage. The polymer is generally added to the medicine given in a capsule of gelatin. The capsule disintegrates quickly in stomach fluid; the surface polymers create a floated mass via hydration and swelling 32,33 . The evolution of the hydrated barrier on the surface monitors medication release. Consistent surface erosion permits the passage of water into the interior layers, and preserves surface hydration and flooding 34 .

Different forms of Non-effervescent Systems are explored below.
1. Bilayer floating tablet: The floating tablet of the two-layer Bilayer has an instant release tablet which releases the initial dosage of the system and the continuous discharge stratum accumulate gastric fluid to the surface, retains the bulk density and remains hovering in the gut ${ }^{6}$.

2. Colloidal gel barrier system: This method extends the stomach retention period and optimizes the quantity of medicines which arrive at the absorption site. It comprises drugs that contain gel-forming hydrocolloids, to keep their stomach content booming. This system includes hydrocolloid cellulose type gel-forming polymers such as hydroxypropyl methyl cellulose (HPMC), polysaccharides and polymers forming matrix, such as polycarbophils, plastics and polyacrylates. Hydrocolloid hydrates in the course of providing an environmental gel colloid barrier when it is in touch with the gastro-intestinal (GI) ${ }^{36,37}$. 


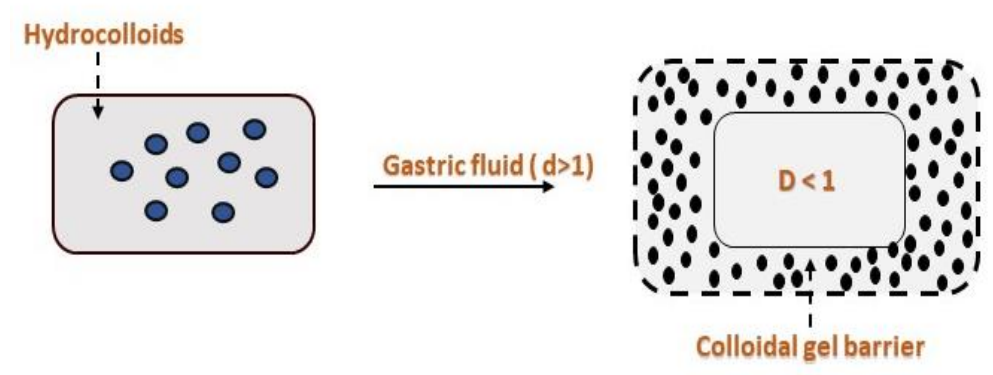

Figure 6: Colloidal gel barrier system

3. Microporous compartment systems: A insoluble medicines in the stomach. The entangled ones are microporous portion features a bundled medication used to float the system on the fluids of the stomach into the reservoir on the upper and base of the wall. The drug fluid orifice, which dissolves the medicines to be container on the outer wall is totally screened to dissolve the metabolized into the bowel ${ }^{38}$.

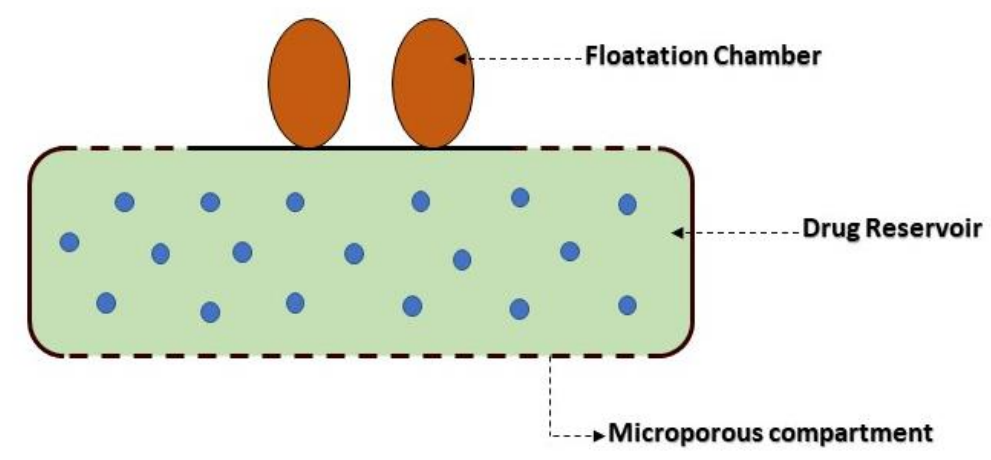

Figure 7: Microporous compartment system.

4. Hollow microspheres: Hollow microballoons used by emulsion solvent diffusion technique, are microballoons that use medicine on the polymer's exterior shell. Solution of ethanol: aqueous dichloromethane and enteric PVA solution at a $400^{\circ} \mathrm{C}$ turning temperature. By vaporising dichloromethane, the resultant gas stage is distributed into polymer gout, producing an internal hollow in a polymeric microsphere, with the pharmaceutical being an internal cavity on the polymer's microsphere. The microballs float on the top of acidic dissolving medium which maintain a surfactant longer than 12 hours (in vitro) ${ }^{35}$.

5. Alginate beads: The floating multi-unit dose forms consist of freezing alginate calcium. Calcium alginate can be precipitated with round beads with $2.5 \mathrm{~mm}$ diameter, which is soluble in calcium chloride solution, which can form a pore system that can strengthen its ability to float over 12 hours and be longer ${ }^{39}$.

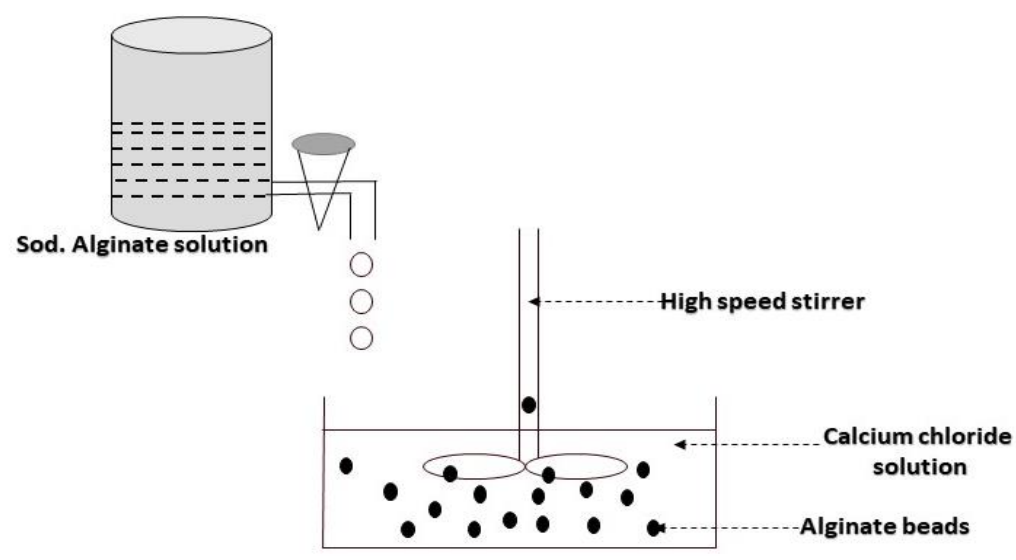

Figure 8: Schematic representation for alginate bead preparation. 
B. Raft Systems: Involve alginate gels in raft forming systems. These have a carbonate element that bubbles in the gel when reacted with stomach acid and allows it to float. The raft process convoluted in the formation comprises the creation, with each part of the fluid swells, of a constant layer called a raft, of viscous cohesion gel in interaction with stomach contents. Due to the low volume density creating CO2 production, this raft floats with stomach juices. The antiacids and medicines supplied for gastrointestinal infection and illnesses have been given great attention in these systems ${ }^{40,41}$.

C. Effervescent System: Preparation is intended for the production of carbon dioxide gas in an effervescent system. Carbonates, gas production and other organic acids are one of them. The formulation design aims at reducing the density system that can float in the stomach juice ${ }^{13}$. In the case of one layered tablet, the free $\mathrm{CO} 2$ gas can be mixed quickly in the tablet matrix 9 .

1. Volatile liquid containing systems: This is a floating system that is osmotically regulated and consists of a void deformable unit in convertible, collapsed shape. Home would be linked to its deformation unit and split into a first and second chamber by a moving unit that is impermeable and sensitive to pressure. The first chamber normally holds an active drug, while the second chamber is used for the production of a gas by vaporization of a volatile fluid such cyclopentane or ether, which allows the drug reservoir to float. With the assistance of an eroding plugs that enabled the vapor to evade, the unit is removed from the gastrointestinal ${ }^{36,37}$. The ethyl cellulose covering is waterpermeable, releasing $\mathrm{CO} 2$ from it ${ }^{42}$.

\section{POLYMERS USED FOR FLOATING DRUG DELIVERY SYSTEM}

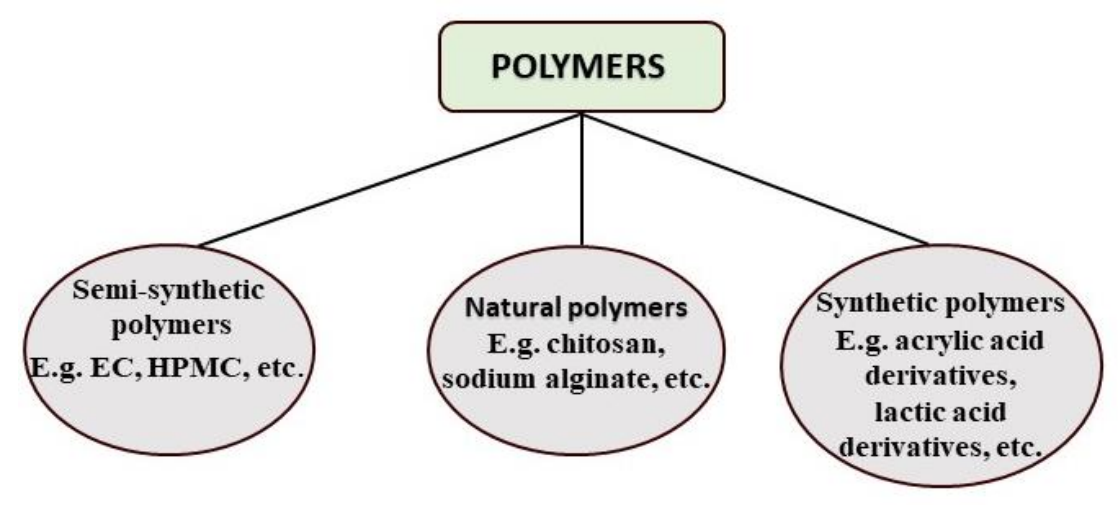

Figure 9: Classification of polymers used on the basis of origin

Some of them are described as below.

1. Chitosan: Chitosan is a bio-poly amino-saccharide, which is synthesized by alkaline chitin deacetylation. The deacetylation grade and molecular weight of chitosan are available in various grade levels, and the solubility may also be modulated from modestly acidic medium to watery 43 . The proportion of deacetylation influences essentially the polymer characteristics of dispersion, hydrophobicity and the potential to interact with polyanions electrostatically by altering the number of amino groups protonatable ${ }^{44,45}$. In $0.5-8 \%$ concentration, chitosan is utilized in production of the microsphere. Acetic acid is utilized primarily as a carrier for the composition preparation at a concentration of $0.5-3$ percent. Dichloromethane and ethanol are also used in some situations in 1:1 ratio $46,47,48,49$.

2. Sodium Alginate: Alginate is a natural abundant component obtained by brown algae and bacteria in the soil ${ }^{50}$. The ionotropic gelation technique is used to produce alginate beads. Beads with a diameter of about $2.5 \mathrm{~mm}$ may be produced, which causes a precipitation of calcium alginate by adding sodium alginate solution in aqueous calcium chloride solutions. The beads are then frozen into liquid nitrogen, separated and freeze at $-40^{\circ} \mathrm{C}$ for 24 hours, which produces a porous structure that is capable of maintaining a floating force of 12 hours. The sodium alginate is used to manufacture beads with $1-6$ percent concentration $^{51,52,53,54}$. The alginate gel particles are $\mathrm{pH}-$ sensitive, that is, they remain unaltered in water or in acid, but quickly swell to a size higher than the original size in phosphate buffers of $\mathrm{pH}$ 7.0. These alginate properties may be of value in medicines which are acid-sensitive as they may be protected against gastric jus attacks and may release xerogels into the gut at desired rates ${ }^{55}$.

3. Ethyl-cellulose And Hydroxy Propyl Methyl Cellulose: A long-chain polymer of b-anhydro-glucosic units combining with acetal linkage is ethyl-cellulose (ethyl ether of the cellulose). The primary hydrophilic vehicle utilized in the manufacturing of oral controlled drug delivery system is hydroxy propyl methyl cellulose (semi-synthetic polymer). It is member of the hydrophilic polymer's family56,57. HPMCs such as $\mathrm{K} 4 \mathrm{M}, \mathrm{K} 100 \mathrm{M}, \mathrm{K} 15 \mathrm{M}$, etc. are utilized in the management of floating microspheres and tablet compounds ${ }^{58,59}$. Ethyl-cellulose is amongst the most often accessed polymers for microsphere preparation. It is also utilized for improved outcomes at concentrations of up to $20 \% 0^{59}$.

4. Acrylic Acid Derivatives: The main derivatives utilized in the production of floating microsphere are Eudragit and Carbopol. Eudragit is an acrylic and methacrylic acid precursor. There are different degrees of Eudragit used to prepare floating microspheres. For the production of floating microspheres, Eudragit RL, E, and RS grades is utilized. RL 100 and RS 100 are granular in these grades and commonly utilized compared to any other plastic, which is $\mathrm{pH}$-independent, mucoadhesive, swelling polymer ${ }^{60,61}$. Carbopol is a variant of acrylic acid that is used for floating foodstuffs because of its high mucoadhesive and swelling characteristics. The floating tablets made with Carbopol and other polymers minimize the floating lag time and also offer a better outcome with Eudragit ${ }^{62,63}$. 


\section{METHOD OF PREPARATION:}

1. Solvent evaporation method: Employing solvent diffusion and evaporation techniques, a hollow inner core was produced with the floating multi-particulate dose. After the polymer is immersed into a solvent, it is dissolved into the organic polymer solution. The drug solution is later homogenized into an aqueous medium of PVA to produce $\mathrm{O} / \mathrm{W}$ emulsion. The organic solvent is then evaporated or continually stirred as the temperature rises. The withdrawal of a solvent leads polymer to seize the gout contact with the oil in water $(\mathrm{O} / \mathrm{W})$, creating a hollow chamber and enabling it to float. Among the polymers that are being used in the improvement of these floating systems include cellulose acetate, polyvinyl acetate, chitosan, acrylate, Eudragit, Methicillin, polyacrylate, polycarbonate, Carbo-polite, polyethylene oxide and agar. The polymer and drug regulation rate were disintegrated by methylene chloride. In the organic phase that was produced the polypropylene powder was then distributed. In the aqueous phase of polyvinyl alcohol (PVA), the resulting suspension was then emulsified. Until being dried in a desiccator with enough silica gel, the macro-particles were tamed and washed with cold water; all of these are uneven in form and size and have a porous structure 65 .

2. Emulsion solvent diffusion method: A new technique of diffusion of emulsion solvents is being implemented with micro-balloons (hollow microspheres) in their external polymer shell. A polymer and medicament mixture are injected into an aqueous polymer solution in ethanol methylene chloride (vinyl alcohol). Enclosed methylene chloride evaporates and the microparticles create interior voids ${ }^{64}$.

3. Ionotropic Gelation Method: In the vicinity of counter-ionic polyelectrolytes, the inclination to cross link promotes ionotropic gelation, which leads to beads production. Since usage of Chitosan, Alginates, CMC and gellan gum for drug encapsulation, this method of gelation has been frequently used to bead preparations. These anions build mesh-like structures by coupling them with versatile cations and engage gelation mostly by combining them with anion chunks. Hydrogel beads are created if the drug-loaded polymer solution is dropped into a versatile cationic aqueous phase 65 .

Table 3: Factors affecting gastric residence time of the floating drug delivery system

\begin{tabular}{|c|c|c|c|}
\hline Factors & Parameters & Intutions & Ref. \\
\hline \multirow[t]{3}{*}{$\begin{array}{l}\text { Formulation } \\
\text { factor }\end{array}$} & Size & $\begin{array}{l}\text { During the digestion process, little pills are quickly evacuated from the stomach } \\
\text { compared to big tablets. }\end{array}$ & 66 \\
\hline & Density & $\begin{array}{l}\text { Density tablets about } 1.0 \mathrm{~g} / \mathrm{ml} \text { were observed to be even more efficacious (typically } \\
\text { regarded lower in density than the stomach contents). }\end{array}$ & \\
\hline & Shape & $\begin{array}{l}\text { In vivo for its stomach retention potential six various types of forms, such as ring } \\
\text { tetrahedron, slurry, pellet, disc, etc., were screened. The tetrahedron form }(2 \mathrm{~cm} \text { in } \\
\text { length), each leg }(3.6 \mathrm{~cm} \text { in diameter), was about } 100 \% \text { retained at } 24 \mathrm{~h} \text { in this } \\
\text { investigation. }\end{array}$ & 67 \\
\hline \multirow[t]{2}{*}{$\begin{array}{l}\text { Idiosyncratic } \\
\text { factors }\end{array}$} & Gender & $\begin{array}{l}\text { average ambulatory GRT in males }(3.4 \mathrm{~h}) \text { below old age and women (4.6 h) } \\
\text { independent of height, body weight and terrain. }\end{array}$ & 68 \\
\hline & Age & $\begin{array}{l}\text { Elderly individuals, particularly those beyond } 70 \text {, are much longer; they float } 39 . \\
\text { Medicine administered also has an impact on illness conditions such as diabetes or } \\
\text { Crohn's disease, etc. }\end{array}$ & 69 \\
\hline \multirow[t]{3}{*}{ Food factors } & $\begin{array}{l}\text { State of Fed } \\
\text { or Unfed }\end{array}$ & $\begin{array}{l}\text { During starvation conditions, GI motility is characterized by periods that occur every } \\
1.5 \text { to } 2 \text { hours with high motor activity and/or the MMC. }\end{array}$ & 70 \\
\hline & Meal's nature & $\begin{array}{l}\text { Injection of undigested polymers or salts of triglycerides can alter the motility pattern } \\
\text { of the gut and therefore reduce the gastric drainage frequency and delay the rate of } \\
\text { drug release. }\end{array}$ & 71 \\
\hline & $\begin{array}{l}\text { Caloric and } \\
\text { frequency of } \\
\text { eating }\end{array}$ & $\begin{array}{l}\text { Floating with a meal heavy in proteins and lipids might be enhanced by four to } 10 \\
\text { hours. When consecutive meals are provided compared to a single meal because of the } \\
\text { low frequency of MMC, floating can be increased by almost } 400 \text { minutes. }\end{array}$ & \\
\hline
\end{tabular}

\section{FDDS PHARMACOKINETICS AND PHARMACODYNAMICS}

\section{Pharmacokinetic Aspects}

* Significantly enhanced Bioavailability: With the exception of several bioavailability reasons, FDDS has examined the excellence of bioavailability for some medicines with narrow therapeutic window attributable only to the poor GI uptake. The medicines evaluated with a restricted absorption window, FDDS, showed that the molecule might be more bioavailable at a particular location. In compared with the intake of traditional formulation, the bioavailability of hovering Riboflavin and Levodopa control release (CR) systems is boosted.
* Enhanced first-pass biotransformation: Similarly, the pre-systemic metabolism of the tested chemical has enhanced the reason for FDDS substantially when supplied sustainedly in the metabolic enzymes (P450 cytochrome, in particular CYP3A4) rather than with bolus input, in the active transport companies with limited capacity activity.

* Decreased dosing frequency: The varied investigations show that medicines with relatively brief, biologicallyliving biological halves, a sluggish input from continuously releasing and controlled floating pharmacokinetics flip-flop system ensured at decreased dosage frequency have been seen. This characteristic is 
linked to better patient conformity and enhances treatment.

* Targeted treatment in the upper GIT for local conditions: For local treatment in the stomach and small intestine, lengthy and continuous use of medication from the floating systems into the gut can be beneficial.

\section{Pharmacodynamic aspects}

* Reduced drug concentration fluctuations: Continuing intake of the drug following controlled release of the Gastro-retentive dosage form (CRGRDF) generates blood concentration in a smaller range in comparison to instant release dosage forms. Fluctuations in drug effects are therefore reduced and concentration can be prevented dependent on maximal dosages. For medications with a low therapeutic index, this is particularly imperative ${ }^{72}$.
* Minimized colon adverse event: In the scenario of a gastro-retentive shape on the gastric in the FDDS the persistence of drug reduces the number of medications reaching the colon. Unwanted drug activity in the colon can therefore be averted. This pharmacodynamic feature offers the justification for floating formulations of betalactam antibiotics which are exclusively absorbed by the small intestine and which cause the growth of bacteria in the colon ${ }^{73}$.

* Reduced body counteractivity: The pharmaceutical reaction, which interferes with natural physiological processes, in many circumstances causes a rebound activity of the body, which reduces drug activity. Low drug intake into the body, as in FDDS, reduces counteractivity and increases drug efficiency.

Table 4: Evaluation of floating drug delivery system

\begin{tabular}{|c|c|c|c|}
\hline S.No & $\begin{array}{l}\text { Evaluating } \\
\text { Parameters }\end{array}$ & Elucidation & Ref. \\
\hline 1. & $\begin{array}{l}\text { Hardness of Floating } \\
\text { tablets. }\end{array}$ & $\begin{array}{l}\text { Twenty tablets should be engaged for hardness measurement by the Monsanto-type } \\
\text { hardness test uniformly sampled in each package of compositions. }\end{array}$ & 74 \\
\hline 2. & $\begin{array}{l}\text { Dimensions of the } \\
\text { tablet. }\end{array}$ & $\begin{array}{l}\text { The length of FDDS tablets is assessed using a Vernier calibrated caliper in the form of a } \\
\text { calibration of traditional comprises, as depict in the official compendium. Three tablets } \\
\text { are randomly selected from each recipe and independently analyzed thickness. }\end{array}$ & \\
\hline 3. & $\begin{array}{l}\text { Determining the } \\
\text { consistency of } \\
\text { medication content. }\end{array}$ & $\begin{array}{l}\text { How much drug is in the formation is the fraction of the drug contents. The boundaries of } \\
\text { acceptable monographs should not be exceeded. The content of the medicine is evaluated } \\
\text { by HPLC, NIRS, HPTLC and ICPAES }\end{array}$ & 75 \\
\hline 4. & Swelling index & $\begin{array}{l}\text { An in vitro measurement device was designed to assess the true floating capacity of } \\
\text { floating dose forms according to time. It works by measuring the force corresponding to } \\
\text { the force } \mathrm{F} \text { needed to keep the item in the fluid completely immersed. This force } \\
\text { determines the resulting weight and may be used to quantify floating or non-floating } \\
\text { properties of the item. }\end{array}$ & 76 \\
\hline 5. & Density of Tablet & $\begin{array}{l}\text { The density of the tablets is regarded to be a significant floating tablet characteristic. The } \\
\text { pill will only float if its density is smaller than gastric fluid (1.004). }\end{array}$ & 77 \\
\hline 6. & $\begin{array}{l}\text { Quantity of } \\
\text { medicines }\end{array}$ & $\begin{array}{l}\text { Five tabs have been considered and pulverized for each group. Powder equivalent to } 100 \\
\text { mg of the medicine was measured, transferred to a beaker glass, adding } 0.01 \mathrm{~N} \mathrm{HCl} \text {, and } \\
\text { agitated for } 5 \text { minutes and added } 0.01 \mathrm{~N} \mathrm{HCl} \text {, which generated up to } 100 \mathrm{ml} \text {, then strained } \\
\text { through the filter paper, Whatman, for a } 15 \text {-minute period. In the conclusion, a mixture } \\
\text { was suitably diluted and then monitored using a UV-Visible spectrophotometer spectro- } \\
\text { photometer by } 203 \text { nanometers. }\end{array}$ & 78 \\
\hline 7. & $\begin{array}{l}\text { Analyses of in vitro } \\
\text { dissolution }\end{array}$ & $\begin{array}{l}\text { Using USP Dissolution Assays Apparatus } 2 \text { the drug release of hydrochloride from } \\
\text { floating tablets is evaluated (paddle method). The dissolving test was performed with } \\
900 \mathrm{ml} 0.1 \mathrm{~N} \mathrm{HCl} \mathrm{for} 12 \text { hours. The solvent sample }(5 \mathrm{ml}) \text { was replaced every hour from } \\
\text { the dissolving device and a fresh dissolution medium was employed. A } 0.45 \mu \mathrm{m} \\
\text { membrane filter filter filtering was applied and the sample was diluted at a concentration } \\
\text { of } 0.1 \mathrm{~N} \text { HCl for } 12 \mathrm{~h} \text {. This solution has been quantified at } 310 \mathrm{~nm} \text { by its transmitter or } \\
\text { absorption. }\end{array}$ & 79 \\
\hline 8. & X-Ray method & $\begin{array}{l}\text { X-Ray has become a fairly popular assessment criteria for floating dosage forms today's } \\
\text { world. It helps to determine dose forms in the GIT and predicts and correlates gastric } \\
\text { emptying time and formulation passage through the Gastrointestinal. The inclusion in a } \\
\text { solid dose form of a radio-opaque material allows for the detection of radiation. }\end{array}$ & 80 \\
\hline 9. & Gastroscopy & $\begin{array}{l}\text { It is composed of a fibereoptical and video system, a peroral endoscopy. Gastroscopy is } \\
\text { advised for visual inspections of the FDDS impact of lengthy stomach stays. Otherwise, } \\
\text { FDDS may be extracted from the stomach for further assessment. }\end{array}$ & 81,82 \\
\hline 10. & Ultrasonography & $\begin{array}{l}\text { Ultrasound waves with a wide range of acoustic resistances on each other allow for the } \\
\text { image of some abdominal organs. Most DFs are not interconnected with a physiological } \\
\text { environment with significant acoustic discrepancies. Ultrasound is therefore not } \\
\text { employed for the FDDS examination on a routine basis. The characterization comprised } \\
\text { evaluating the intragastric site of the hydrogels, gel penetration of the solvent and FDDS } \\
\text { linkages during the period of peristalsis. }\end{array}$ & 83 \\
\hline
\end{tabular}




\section{CONCLUSION}

Drug absorption is a very varied operation in the gut, and prolonged stomach retention of the dose form prolonged the permeation period. FDDS provides a possible gastro retention strategy. The objective is to increase bioavailability in the area of the gastrointestinal system with a small absorption window. By lengthening GI time, the solubility of medicinal products less soluble at high $\mathrm{pH}$ and reducing the waste of medicines is improved, thereby reducing plasma levels. While some challenges to produce extended gastric retention still need to be developed, a great number of firms focus on the commercialization of this method.

\section{REFERENCES}

1- Dubey, J., \& Verma, N. Floating drug delivery system: a review: International Journal of Pharmaceutical Sciences and Research, 2013; 4(8):2893.

2- Niharika, M. G., Krishnamoorthy, K. A. N. N. A. N., \& Akkala, M. A. D. H. U. K. A. R. Overview on floating drug delivery system: Int J App Pharm, 2018; 10(6):65-71. https://doi.org/10.22159/ijap.2018v10i6.28274

3- Deshpande, A. A., Rhodes, C. T., Shah, N. H., \& Malick, A. W. Controlled-release drug delivery systems for prolonged gastric residence: an overview: Drug Development and Industrial Pharmacy, 1996; 2(6):531-539. https://doi.org/10.3109/03639049609108355

4- Whitehead, L., Fell, J. T., \& Collett, J. H. Development of gastroretentive dosage form: European Journal of Pharmaceutical Sciences, 1996; (4S):182. https://doi.org/10.1016/S09280987(97)86558-X

5- SOPYAN, I., \& WAHYUNINGRUM, R. A review: Floating drug delivery system as a tool to improve dissolution rate in gastric: International Journal of Applied Pharmaceutics, 2020:51-54. https://doi.org/10.22159/ijap.2020v12i4.38415

6- Garg, S., \& Sharma, S. Gastro-retentive drug delivery systems. Business Briefing: Pharma-tech, 2003; 5(2).

7- Vedha, H., \& Chaudhary, J. The recent developments on gastric floating drug delivery system: An overview. Journal of Pharmaceutical Technology and Research, 2010; 2(1):524-34.

8- Dangi, S., Chakraborty, A. K., \& GANJU, K. Recent Technological Approaches on Floating Drug Delivery System: International Journal on Current Trends in Drug Development \& Industrial Pharmacy; 2017; 1(1)2581-7655 (online)].

9- Arora, S., Ali, J., Ahuja, A., Khar, R. K., \& Baboota, S. Floating drug delivery systems: a review: AAPS Pharm-SciTech, 2005; 6(3):E372-E390. https://doi.org/10.1208/pt060347

10- Chavanpatil, M. D., Jain, P., Chaudhari, S., Shear, R., \& Vavia, P. R. Novel sustained release, swellable and bioadhesive gastroretentive drug delivery system for ofloxacin: International journal of pharmaceutics, 2006; 316(1-2):86-92. https://doi.org/10.1016/j.ijpharm.2006.02.038

11- Klausner, E. A., Lavy, E., Friedman, M., \& Hoffman, A. Expandable gastro-retentive dosage forms: Journal of controlled release, 2003; 90(2): 143-162. https://doi.org/10.1016/S01683659(03)00203-7

12- Joshi, P., Patel, P., Modi, H., Patel, M. R., Patel, K. R., \& Patel, N. M. (2012). A review on gastro-retentive drug delivery system: Journal of Pharmaceutical Science and Bioscientific Research, 2012; 2(3):123-128.

13- Singh, B. N., \& Kim, K. H. Floating drug delivery systems: an approach to oral controlled drug delivery via gastric retention: Journal of Controlled release, 2000; 63(3):235-259. https://doi.org/10.1016/S0168-3659(99)00204-7

14- Desai, S., \& Bolton, S. A floating controlled-release drug delivery system: in vitro-in vivo evaluation: Pharmaceutical research,
1993; 10(9):1321-1325.

https://doi.org/10.1023/A:1018921830385

15- Umamaheshwari, R. B., Jain, S., Bhadra, D., \& Jain, N. K. Floating microspheres bearing acetohydroxamic acid for the treatment of Helicobacter pylori: Journal of pharmacy and pharmacology, 2003; 55(12):1607-1613.

https://doi.org/10.1211/0022357022223

16- Jain, S. K., Awasthi, A. M., Jain, N. K., \& Agrawal, G. P. Calcium silicate-based microspheres of repaglinide for gastro-retentive floating drug delivery: Preparation and in vitro characterization: Journal of controlled release, 2005; 107(2):300-309. https://doi.org/10.1016/j.jconrel.2005.06.007

17- Syan, N., Mathur, P., Saroha, K., Verma, S., \& Kumar, V. Floating drug delivery system: An innovative acceptable approach in gastro-retentive drug delivery: Arch. Apll. Sci. Res, 2010; 2(2): 57-270.

18- Sopyan, I., \& Wahyuningrum, R. A review: Floating drug delivery system as a tool to improve dissolution rate in gastric: International Journal of Applied Pharmaceutics, 2020: 51-54. https://doi.org/10.22159/ijap.2020v12i4.38415

19- Chandel, A., Chauhan, K., Parashar, B., Kumar, H., \& Arora, S. Floating drug delivery systems: A better approach: International Current Pharmaceutical Journal, 2012; 1(5):119-127. https://doi.org/10.3329/icpj.v1i5.10283

20- Shah, S. H., Patel, J. K., \& Patel, N. V. Stomach specific floating drug delivery system: A review. Int J Pharm Tech Res, 2009; 1(3):623-33.

21- Hwang, S. J., Park, H., \& Park, K. Gastric retentive drug-delivery systems: Critical Reviews ${ }^{\mathrm{TM}}$ in Therapeutic Drug Carrier Systems, 1998; 15(3). https://doi.org/10.1615/CritRevTherDrugCarrierSyst.v15.i3.20

22- Gopalakrishnan, S., \& Chenthilnathan, A. Floating drug delivery systems: A Review: Journal of Pharmaceutical Science and Technology, 2011; 3(2):548-554.

23- Vedha, H., \& Chaudhary, J. The recent developments on gastric floating drug delivery system: An overview: Journal of Pharmaceutical Technology and Research, 2010; 2(1):524-34.

24- Silang, R., Regalado, M., Cheng, T. H., \& Wesson, D. E. Prokinetic agents increase plasma albumin in hypoalbuminemic chronic dialysis patients with delayed gastric emptying: American journal of kidney diseases, 2001; 37(2):287-293. https://doi.org/10.1053/ajkd.2001.21291

25- Kamalakkannan, V., Puratchikody, A., Prasanth, V. V., \& Masilamani, K. Enhancement of drugs bioavailability by floating drug delivery system-A review: International Journal of Drug Delivery, 2011; 3(4):558.

26- Suryawanshi, A., \& Hiremath, S. P. Floating Drug Delivery System-A Review: American Journal of Pharmatech Research, 2011; 2(1):138-53.

27- Mantry, S., Thilothama, L. R., \& Shashanka, D. Formulation and in vitro evaluation of metoprolol succinate floating tablets by using two viscosity grades of HPMC: International Journal of Pharmaceutical Sciences and Research, 2012; 3(9):3507.

28- Hwang, S. J., Park, H., \& Park, K. Gastric retentive drug-delivery systems: Critical Reviews ${ }^{\mathrm{TM}}$ in Therapeutic Drug Carrier Systems, 1998; 15(3).

https://doi.org/10.1615/CritRevTherDrugCarrierSyst.v15.i3.20

29- Sabale, V., Sakarkar, S., Pund, S., \& Sabale, P. Formulation and evaluation of floating dosage forms: An overview. Systematic Reviews in Pharmacy, 2010; 1(1):33. https://doi.org/10.4103/0975-8453.59510

30- Datir, S. K., Patil, P. B., \& Saudagar, R. B. Floating type drug delivery system: a review: Journal of Drug Delivery and Therapeutics, 2019; 9(2):428-432. https://doi.org/10.22270/jddt.v9i2.2492 
31- Rocca, J. G., Omidian, H., \& Shah, K. Progresses in gastroretentive drug delivery systems. Business Briefing: Pharma Tech, 2003; 152-156.

32- Menon, A., Ritschel, W. A., \& Sakr, A. Development and evaluation of a monolithic floating dosage form for furosemide: Journal of pharmaceutical sciences, 1994; 83(2):239-245. https://doi.org/10.1002/jps.2600830225

33- Oth, M., Franz, M., Timmermans, J., \& Möes, A. The bilayer floating capsule: a stomach-directed drug delivery system for misoprostol: Pharmaceutical research, 1992; 9(3):298-302. https://doi.org/10.1023/A:1015870314340

34- Gohel, M. C., Mehta, P. R., Dave, R. K., \& Bariya, N. H. A more relevant dissolution method for evaluation of a floating drug delivery system. Dissolution technologies, 2004; 11:22-26. https://doi.org/10.14227/DT110404P22

35- Mayavanshi, A. V., \& Gajjar, S. S. Floating drug delivery systems to increase gastric retention of drugs: A Review: Research Journal of Pharmacy and Technology, 2008; 1(4):345-348.

36- Timmermans, J., \& Moës, A. J. How well do floating dosage forms float? : International journal of pharmaceutics, 1990; 62(23):207-216. https://doi.org/10.1016/0378-5173(90)90234-U

37- Joseph, N. J., Lakshmi, S., \& Jayakrishnan, A. A floating-type oral dosage form for piroxicam based on hollow polycarbonate microspheres: in vitro and in vivo evaluation in rabbits: Journal of controlled release, 2002; 79(1-3):71-79. https://doi.org/10.1016/S0168-3659(01)00507-7

38- Avinash, K., Abha, D., Praween, K., \& Abhinav, G. Floating drug delivery system a significant tool for stomach specific release of cardiovascular drugs: Int. J. Drug Dev. \& Res, 2012; 4(4):116129.

39- Sarawade, A., Ratnaparkhi, M. P., \& Chaudhari, S. Floating drug delivery system: an overview: International Journal of Research and Development in Pharmacy \& Life Sciences, 2014; 3(5):1106-1115. https://doi.org/10.22270/jddt.v3i4.579

40- Prajapati, V. D., Jani, G. K., Khutliwala, T. A., \& Zala, B. S. Raft forming system-an upcoming approach of gastroretentive drug delivery system: Journal of controlled release, 2013; 168(2):151-165. https://doi.org/10.1016/j.jconrel.2013.02.028

41- Jayanthi G, Jayaswal SB, Srivastava AK. Formulation and evaluation of terfenadine microbaloons for oral controlled release. Pharmazie, 1995; 5:769-770.

42- Devtalu, S. V., Patil, A. E., Bari, M. M., \& Barhate, S. D. A Review on Novel Approach-Bi-layer Tablet Technology: Int. J. Pharm. Sci. Rev. Res, 2013; 21(1):46-52.

43- Kumar, M. N. R. A review of chitin and chitosan applications. Reactive and functional polymers, 2000; 46(1):1-27. https://doi.org/10.1016/S1381-5148(00)00038-9

44- Kiang, T., Wen, J., Lim, H. W., \& Leong, K. W. The effect of the degree of chitosan deacetylation on the efficiency of gene transfection. Biomaterials, 2004; 25(22):5293-5301. https://doi.org/10.1016/j.biomaterials.2003.12.036

45- Huang, M., Fong, C. W., Khor, E., \& Lim, L. Y. Transfection efficiency of chitosan vectors: effect of polymer molecular weight and degree of deacetylation: Journal of controlled release, 2005; 106(3):391-406. https://doi.org/10.1016/j.jconrel.2005.05.004

46- Garud, A., \& Garud, N. Preparation and evaluation of chitosan microcapsules of metronidazole using tripolyphosphate crosslinking method: Dhaka University Journal of Pharmaceutical Sciences, 2010; 9(2):125-130. https://doi.org/10.3329/dujps.v9i2.7897

47- Li, X. W., \& Yang, T. F. Fabrication of ethyl cellulose microspheres: Chitosan solution as a stabilizer: Korean Journal of Chemical Engineering, 2008; 25(5):1201-1204. https://doi.org/10.1007/s11814-008-0198-8

48- Varshosaz, J., Jaffarian Dehkordi, A., \& Golafshan, S. Colonspecific delivery of mesalazine chitosan microspheres: Journal of microencapsulation, 2006; 23(3):329-339.

https://doi.org/10.1080/02652040600612405

49- Senthilkumar, S. K., Jaykar, B., \& Kavimani, S. Formulation and evaluation of gastroretentive floating drug delivery system of rabeprazole sodium: Int J Biopharm, 2011; 2(2):57-62.

50- Draget, K. I., Skjåk-Bræk, G., \& Smidsrød, O. Alginate based new materials: International journal of biological macromolecules, 1997; 21(1-2):47-55. https://doi.org/10.1016/S01418130(97)00040-8

51- Kawatra, M., Jain, U., \& Ramana, J. Recent advances in floating microspheres as gastro-retentive drug delivery system: A review. Int J Recent Adv Pharm Res, 2012; 2(3):5-23.

52- Dehghan, M., \& Kha, F. Gastroretentive drug delivery systems: A patent perspective: International Journal of Health Research, 2009; 2(1). https://doi.org/10.4314/ijhr.v2i1.55385

53- Kshirsagar, S. J., Patil, S. V., \& Bhalekar, M. R. Statistical optimization of floating pulsatile drug delivery system for chronotherapy of hypertension. International journal of pharmaceutical investigation, 2011; 1(4):207. https://doi.org/10.4103/2230-973X.93005

54- Bhatt, P., Patel, D., \& Chaudhari, R. Formulation and evaluation of floating beads for chronotropic delivery of lornoxicam: World J Pharm Res, 2012; 1:738-56.

55- Yotsuyanagi, T., Ohkubo, T., Ohhashi, T., \& Ikeda, K. E. N. Calcium-induced gelation of alginic acid and $\mathrm{pH}$-sensitive reswelling of dried gels. Chemical and Pharmaceutical Bulletin, 1987; 35(4):1555-1563. https://doi.org/10.1248/cpb.35.1555

56- Rowe, R. C., Sheskey, P., \& Quinn, M. Handbook of pharmaceutical excipients. Libros Digitales-Pharmaceutical Press. 2009.

57- Ghosal, K., Chakrabarty, S., \& Nanda, A. Hydroxypropyl methylcellulose in drug delivery. Der pharmacia sinica, 2011; 2(2):152-168

58- Barhate, S. D., Rupnar, Y. S., Sonvane, R. M., Pawar, K. R., \& Rahane, R. D. Formulation and evaluation of floating microspheres of ketorolac trometamol: Int J Pharm Res Dev, 2009; 1:1-8.

59- Pande, A. V., Vaidya, P. D., Arora, A., \& Dhoka, M. V. In vitro and in vivo evaluation of ethyl cellulose based floating microspheres of cefpodoxime proxetil: Int J Pharm Biomed Res, 2010; 1(4):122128.

60- Joshi, M. Role of eudragit in targeted drug delivery: Int J Curr Pharm Res, 2013; 5(2):58-62.

61- Sonje, A., \& Chandra, A. Comprehensive review on Eudragit polymers: Int. Res. J. Pharm, 2013; 4(5):2230-8407. https://doi.org/10.7897/2230-8407.04515

62- Rad, R. T., Jafari-Azar, Z., \& Mortazavi, S. A. Formulation and evaluation of captopril floating matrix tablets based on gas formation: African Journal of Pharmacy and Pharmacology, 2013; 7(35):2438-2444 https://doi.org/10.5897/AJPP2013.3531

63- Vandana, P., Nisha, V., Kausalya, J., Vaijayanthi, V., \& Ravichandiran, V. Formulation and evaluation of gastro retentive floating tablets of atenolol. 2011.

64- Lende, L. K. L. K., Banerjee, S. K., Gadhave, M. V., Gaikwad, D. D., \& Gaykar, A. J. Review on: Bilayer floating tablet: Asian Journal of Pharmaceutical Research and Development, 2013; 31-39.

65- Thakur, S., Ramya, K., Shah, D. K., \& Raj, K. Floating Drug Delivery System: Journal of Drug Delivery and Therapeutics, 2021; 11(3-S):125-130. https://doi.org/10.22270/jddt.v11i3 S. 4828

66- Jassal, M., Nautiyal, U., Kundlas, J., \& Singh, D. A review Gastroretentive drug delivery system (GRDDS): Indian journal of pharmaceutical and biological research, 2015; 3(01):82-92. https://doi.org/10.30750/ijpbr.3.1.13 
67- Ichikawa, M., Watanabe, S., \& Miyake, Y. A new multiple-unit oral floating dosage system. I: Preparation and in vitro evaluation of floating and sustained-release characteristics: Journal of pharmaceutical sciences, 1991; 80(11):1062-1066. https://doi.org/10.1002/jps.2600801113

68- Uddin, M., Rathi, P. B., Siddiqui, A. R., Sonawane, A. R., \& Gadade, D. D. Recent development in floating delivery systems for gastric retention of drugs an overview: Asian Journal of Biomedical and Pharmaceutical Sciences, 2011; 1(3):26-42.

69- Chueh, H. R., Zia, H., \& Rhodes, C. T. Optimization of sotalol floating and bioadhesive extended-release tablet formulations: Drug development and industrial pharmacy, 1995; 21(15):1725-1747. https://doi.org/10.3109/03639049509069261

70- Gu, T. H., Chen, S. X., Zhu, J. B., Song, D. J., Guo, J. Z., \& Hou, H. M. Pharmacokinetics and pharmacodynamics of diltiazem floating tablets. Zhongguo yao li xue bao= Acta Pharmacologica Sinica, 1992; 13(6):527-531.

71- Rouge, N., Cole, E. T., Doelker, E., \& Buri, P. Buoyancy and drug release patterns of floating minitablets containing piretanide and atenolol as model drugs: Pharmaceutical development and technology, 1998; 3(1):73-84. https://doi.org/10.3109/10837459809028481

72- Ghule, P. N., Deshmukh, A. S., \& Mahajan, V. R. Floating Drug Delivery System (FDDS): An Overview: Research Journal of Pharmaceutical Dosage Forms and Technology, 2014; 6(3):174.

73- Rubinstein, A., \& Friend, D. R. Specific delivery to the gastrointestinal tract. polymeric site-specific Pharmacotherapy: Wiley, Chichester, 1994; 282-283.

74- Shivhare, U. D., Chilkar, P. M., Bhusari, K. P., \& Mathur, V. B. Formulation and Evaluation of Floating Matrix Tablet for Controlled Drug Release: Digest Journal of Nanomaterials and Biostructures, 2011; 6:4-5.
75- Yuvarej ST, Pushpendra SN, Garima RO. Devolpment and evaluation of floating microsperes of verapamil hydrochloride: Brazilian J Pharm Sci 2007; 43:529-34. https://doi.org/10.1590/S1516-93322007000400005

76- Ritschel, W. A. Targeting in the gastrointestinal tract: new approaches: Methods and findings in experimental and clinical pharmacology, 1991; 13(5):313-336.

77- PRABHA, K., Sunil, S., \& KUMAR, A. V. Approaches to increase the gastric residence time: floating drug delivery systems-a review: Asian J Pharm Clin Res, 2013; 6(3):1-9.

78- Singh, S., Prajapati, K., Pathak, A. K., \& Mishra, A. Formulation and evaluation of floating tablet of captopril: International Journal of Pharm-Tech Research, 2011; 3(1):333-341.

79- Kumari, S. D., Vengatesh, S., Elango, K., Damayanthi, R. D., Deattu, N., \& Christina, P. Formulation and evaluation of floating tablets of ondansetron hydrochloride: International Journal of Drug Development \& Research: 2012; 4:265-273.

80- Klausner, E. A., Lavy, E., Barta, M., Cserepes, E., Friedman, M., \& Hoffman, A. Novel gastro-retentive dosage forms: evaluation of gastro-retentivity and its effect on levodopa absorption in humans: Pharmaceutical research: 2003; 20(9): 1466-1473. https://doi.org/10.1023/A:1025770530084

81- Van Gansbeke, B., Timmermans, J., Schoutens, A., \& Moës, A. Intragastric positioning of two concurrently ingested pharmaceutical matrix dosage forms: International journal of radiation applications and instrumentation: 1991; 18(7):711718. https://doi.org/10.1016/0883-2897(91)90009-A

82- Jao, F., Edgren, D. E., \& Wong, P. S. Gastric retention dosage form having multiple layers: Int Application W00038650: 2006.

83- Hendee, W. R. In Textbook of Diagnostic Imaging II. WB Saunders, Philadelphia: 1999; 1:1-6. 